\title{
RADVILŲ DVARO ISTORIJŲ ARUODAI
}

\author{
Marta Zigmantaitè \\ Vilniaus Gedimino technikos universitetas, Architektūros pagrindu ir teorijos katedra, \\ Pylimo g. 26/Trakug. 1, 01132 Vilnius, Lietuva \\ El.paštasneroves@gmail.com
}

Itteikta 201206 15; priimta 20120705

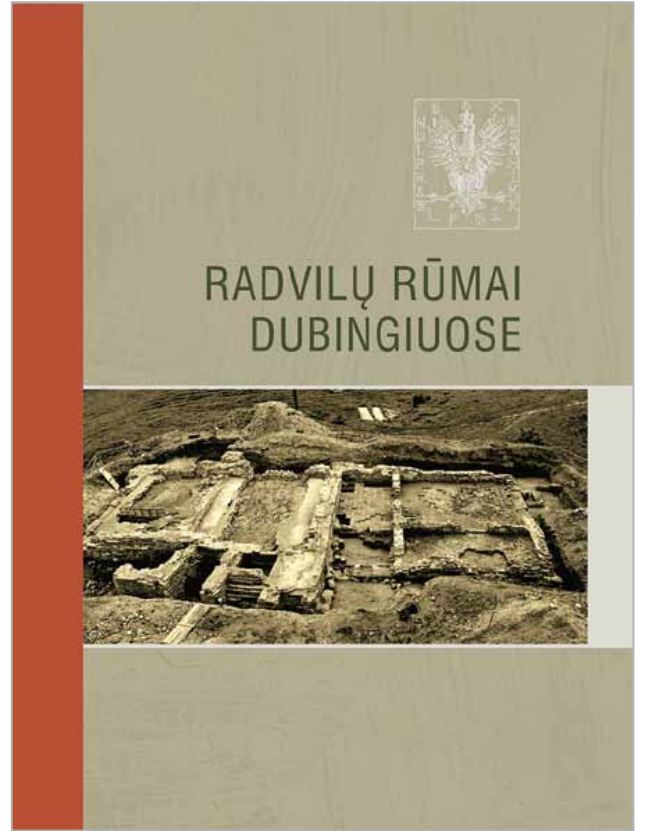

Radvilų giminė buvo viena reikšmingiausių ir ịtakingiausių giminių LDK laikais. Nuo $2003 \mathrm{~m}$. vykdyti intensyvūs Dubingių archeologiniai kasinèjimai parodè, jog būtent ši vieta yra išeitinis Radvilų giminès taškas. Tyrimui rezultatai $2009 \mathrm{~m}$. buvo pateikti kolektyvinèje monografijoje „Radvilų tèvonija Dubingiuose“ (autoriai - prof. dr. Albinas Kuncevičius, doc. dr. Rimvydas Laužikas, prof. habil. dr. Rimvydas Jankauskas, Indre Rutkauskaitè ir Daina Stankevičiūtè) ${ }^{1}$, kuri patvirtina,

\footnotetext{
1 Kuncevičius, A.; Laužikas, R.; Rutkauskaite, I.; Šmigelskas, R. 2011. Radvilu rūmai Dubingiuose. Vilnius: Vilniaus universiteto leidykla. 157 p.
}

kad gausūs, sensacingi ir informatyvūs Dubingių kasinëjimų radiniai yra tiesiausias kelias ị Radvilų giminès gyvenimo peripetijas.

Tęsiant Dubingių kasinëjimus ir vis atrandant daugiau informacijos, garbus autorių kolektyvas - prof. dr. Albinas Kuncevičius, doc. dr. Rimvydas Laužikas, Indrè Rutkauskaitè ir Ramūnas Šmigelskas - 2011 m. išleido monografiją „Radvilų rūmai Dubingiuose“. Knygoje pristatomi 2005-2011 m. Dubingių piliavietès buvusių rūmų vietos tyrimų rezultatai, kurie neabejotinai prisideda prie Lietuvos istorijos spragų pildymo ir leidžia atidžiau pažvelgti i Radvilu dvaro gyvenimą iš arčiau.

Monografija unikali ir įdomi tuo, kad joje pristatomi Dubingių piliavietes tyrimai ịvairiais tarpdalykiniais aspektais. Visų pirma, knygoje debiutuoja pirmieji didelio ir sudettingo Dubingių mikroregiono tyrimų projekto rezultatai - Dubingių mikroregiono apgyvendinimo ir administracinių ribų raida XIII-XIX a. $2011 \mathrm{~m}$. pradèti tyrimai numatomi pabaigti per artimiausius ketverius metus. Šis tyrimas leidžia tiksliai apibrèžti regiono dydi, svarbą ir išskirtinius bruožus.

Antra, monografijoje glaustai, tačiau informatyviai ir iliustratyviai pateikiami reikšmingiausi istoriniai ir archeologiniai duomenys, susiję su Dubingių piliaviete ir Radvilų rūmais. Autoriai puikiai suvaldo istorinius šaltinius ir papildo juos atliktais naujausiais archeologiniais tyrimais. Pateikiama informacija leidžia suvokti Dubingių išskirtinumą, Radvilų giminès svarbą Lietuvos istorijoje bei suteikia žinių apie pačią rezidenciją architektūriniu bei archeologiniu aspektu.

Priešpaskutinè knygos dalis skiriama XVI-XVIII a. Radvilų dvaro valgymo kultūrai. Be abejonių, toks tyrimas yra reikšmingas indèlis Lietuvos kulinarijos ir di- 
dikų kasdienybės istorijoje, tačiau kartu įrodo, kokius svarbius, įdomius ir unikalius interpretacinius rezultatus galima gauti, atlikus archeologinius bei istorinius vietos tyrimus.

Paskutinè knygos dalis galètų būti pavadinta vienu kūrybingiausių sprendimų tokio pobūdžio monografijoje ir visame Dubingių tyrime plačiąja prasme. Ši dalis skirta pristatyti Radvilu dvarvietès išsaugojimo ir pritaikymo lankyti projektams. Lietuviška patirtis rodo, jog dažnai paveldosauginiai išsaugojimo projektai visuomenę pasiekia pradèti ar jau pabaigti iggyvendinti, nepateikus jokių aiškių pasirinkimo motyvų. Monografijoje „Radvilų rūmai Dubingiuose“ visas skyrius skirtas aptarti realiai atkastų rūmų liekanų situacijai, išsaugojimo tikslams bei paskelbto konkurso pritaikymo visuomenès poreikiams - dalyvavusiems projektams. Visus projektus lydi pristatymas, vizualizacijos ir svarbiausia - komentaras, realiai ịvertinant ju tinkamumą ir motyvaciją dèl pasirinkimo arba atmetimo. Tokio pobūdžio visuomenès informavimo būdas yra atviras ir atskleidžiantis autorių rūpestị dèl tolesnio Radvilų dvarvietés likimo ir eksponavimo.

Radvilų rūmų daugiaplaniški tyrimai yra neišsemiamas Lietuvos politinès, architektūrinès, socialinès istorijos šaltinis. Neabejotina, kad ši monografija sudomins kiekvieną neabejingą LDK istorijai ir praskins kelius it tolesnius sèkmingus Dubingių tyrimus, to ir galima palinkèti autoriams. 